WellBeing International

WBI Studies Repository

$1-1994$

\title{
Transportation of animals and welfare
}

D. B. Adams

Bureau of Resource Sciences (Australia)

Follow this and additional works at: https://www.wellbeingintlstudiesrepository.org/trafani

Part of the Agribusiness Commons, Animal Studies Commons, and the Operations and Supply Chain Management Commons

\section{Recommended Citation}

Adams, D. B. (1994). Transportation of animals and welfare. Revue Scientifique et Technique de l'Office International des Epizooties, 13(1), 153-170. http://dx.doi.org/10.20506/rst.13.1.760

This material is brought to you for free and open access by WellBeing International. It has been accepted for inclusion by an authorized administrator of the WBI Studies Repository. For more information, please contact wbisr-info@wellbeingintl.org.

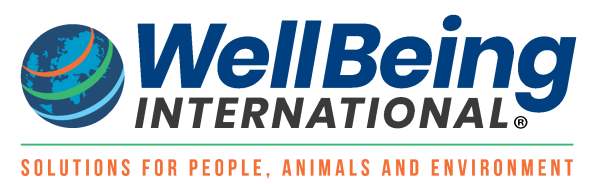


Rev. sci. tech. Off. int. Epiz., 1994, 13 (1), 153-169

\title{
Transportation of animals and welfare
}

\author{
D.B. ADAMS *
}

\begin{abstract}
Summary: All forms of transport are potentially hazardous for animals, regardless of whether travel is between or within countries, or by road, rail, air or sea. However, experience shows that animals can be transported under suitable conditions without harm to their welfare.

The provision of suitable conditions and the establishment of a mutually satisfactory framework for regulating the international transport of animals depends on an understanding of welfare needs and of the biological basis for disease, stress and suffering. The author examines the biological aspects of this framework.

The capacity of animals to adapt to the different demands of different forms of transport varies with the species and physical state of animals being transported. Key practicalities are the preparation and selection of animals before transport, the provision of suitable environments, feed, water and rest during transport, and arrangements for recuperation after transport. Animals which are compromised by disease or injury must be excluded.
\end{abstract}

KEYWORDS: Animal welfare - Disease - Stress - Transport.

\section{INTRODUCTION}

Animals are valued by people for social, cultural, economic and emotional reasons: they provide food, fibre and companionship, are used in sport, recreation and scientific study, and have increasing importance as environmental assets in their own right. Animals are transported between nations for all these reasons, and the traffic involved is a significant part of global trading and cultural exchange. This traffic will continue in the future and can be expected to increase with the growing international mobility of people and improvements in forms of transportation. Consequently, concern regarding the welfare of transported animals has heightened, and interest has intensified in policies for the protection of these animals.

Experience over a long period and throughout the world demonstrates that animals can travel between countries by modern forms of transportation without suffering harm. However, all modes of international transport are potentially hazardous and may be associated with disease, stress and suffering. This article addresses some of the biological and practical considerations involved in protecting the welfare of animals, and builds upon earlier comprehensive overviews of the subject (30).

* Bureau of Resource Sciences, Department of Primary Industries and Energy, John Curtin House, 22 Brisbane Avenue, Barton, Canberra ACT 2600, Australia. 


\section{NATURE AND MAGNITUDE OF INTERNATIONAL TRANSPORT OF ANIMALS}

International transport of animals refers to the transport of animals from one country to another, perhaps by way of intermediate countries, and involves the crossing of international frontiers. Transport may occur by road, rail, air or sea and may take short or long periods of time. For an island continent, such as Australia, international transport automatically refers to ships and aircraft, while within Australia animals may be transported by both road and rail for distances as long as, or longer than those for international transport elsewhere in the world.

If conditions are suitable, distances and time are not overriding considerations for the welfare of animals during international transport. Indeed, the welfare issues for animals are the same regardless of whether journeys occur between or within countries. The central concern for international transport is the way in which responsibilities for the protection of animals are to be shared between nations. In this regard, animal welfare is an issue for international concern, in a similar way to the prevention of the transmission of infectious and parasitic diseases by transported animals.

\section{Magnitude of international traffic of animals}

Comprehensive statistics on the international transport of animals are not easily available. However, an indication of the magnitude of this trade is given in Figure 1.

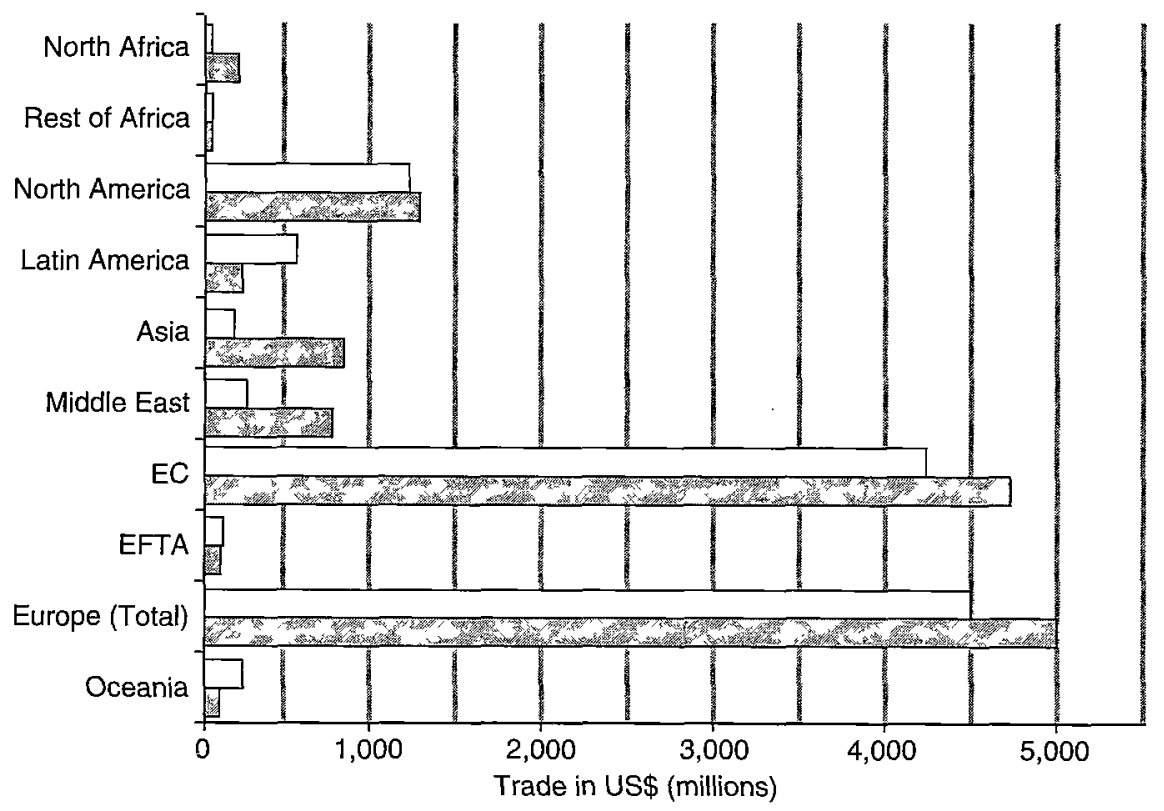

EC: European Community

EFTA: European Free Trade Agreement

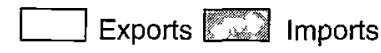

Frg. 1

Monetary value of world trade in live animals for food in 1990 
This Figure shows only the value of trade in live animals for food. The inclusion of transport of animals for other reasons would increase the total world figures for imports and exports of US\$8,364 million and US $\$ 7,034$ million, respectively. In addition, monetary values distort the relative importance of the international transport of animals for individual nations and regions.

\section{The future for international transport of animals}

Closer trading and cultural ties between nations and the strong bonds which can be formed between people and animals make it likely that international transport of animals will continue. Paradoxically, this trend may not be arrested by advances in reproductive technologies which allow transport of semen, ova and embryos. There may be occasions when the international transfer of intact animals as donors of semen or ova is a rational strategy in a breeding programme based on these technologies.

A further stimulus to continued international transport of animals is likely to come from endeavours to preserve animal genetic resources and to maintain genetic diversity. This will involve a large-scale co-operative effort. The global exchange of animals between regions may be a key strategy and will require international transport.

\section{BIOLOGICAL BACKGROUND TO WELFARE, STRESS AND DISEASE}

Welfare, stress and disease are inter-related concepts which require explanation before they can be situated in the context of international transport. The connections between these concepts can be explained with reference to the definition of welfare as "the state of an individual [animal] as regards its attempts to cope with its environment" (14). The key words here are "state" and "individual", meaning that stress and disease provoke welfare concern because they have an impact on the state of an individual animal. Concern for populations of animals and the sustainability of these populations in the future is usually placed within the arena of conservation.

Low incidences of disease and stress are indicators of both good welfare and good health. As a result, statistics of disease and mortality provide basic information for epidemiological analyses of welfare problems associated with transport. These statistics have additional value as part of quality assurance for adequate welfare.

\section{Welfare}

Since welfare refers to the "state" of an animal and since "states". arise from the operation of life processes, welfare can be validly described and appraised by the language and principles of biology, and is therefore a suitable subject for scientific analysis. For this reason, and notwithstanding important reservations about a "pure science model of animal welfare" (46), science can provide a common frame of reference for international discussions on the welfare of animals during transport. This includes all aspects of science, particularly science as "systematised knowledge". Methodical use must be made of the "common-sense" knowledge on transportation welfare which has been derived from practical experience.

Animal welfare is a matter for both science and morality, and neither domain, acting alone, can adequately explain the issue or provide the answers. The scientific and moral aspects of welfare are mutually dependent, and the relationship between these two 
aspects can be viewed as follows: science provides the methods and understanding necessary for describing and appraising the state of an animal in the light of welfare criteria; the processes for determining what is acceptable or unacceptable and for setting standards fall within the scope of morality.

The deficiencies in human care which lead to poor animal welfare form the connection with ethics and morality. These deficiencies take three forms: abuse, neglect and deprivation (16). Abuse and neglect are considered as "direct inhumanity" (22): abuse refers to the deliberate maltreatment of animals; neglect refers to maltreatment which results from laziness, ignorance or overwork. By contrast, deprivation relates to "contingent inhumanity" (22) and occurs when animals are prevented from satisfying physiological and behavioural needs. Deprivation can be a difficult concept and can result in a range of states. Some of these states may raise clear-cut welfare concerns, while others may be problematic or raise no welfare concerns at all.

\section{A model or "mental picture" of welfare}

As remarked above, the concept of animal welfare refers to the state of an animal, not to human care. However, the question arises of what element of the state of an animal provokes concern - other than the practical and common-sense benefit of having healthy animals which are economically productive and undamaged by the process of transportation. The answer is that animals may possibly have subjective experience, a certain degree or form of consciousness or awareness; that they are capable of feeling and, accordingly, may suffer. Suffering, in this connection, refers to the subjectively unpleasant tones of feeling or affect which can occur in a range of circumstances, and may accompany states such as pain, stress, disease, fear, frustration, hunger, thirst, nausea, malaise and depression. The concept of animal suffering provides the basis for the welfare interest in the above states whenever they occur, and this includes the circumstances of international transport.

The problem of subjective experience in animals and the private nature of such experience has been a challenge for progress in animal welfare. Questions of mind and awareness in animals lie at the heart of the matter and are being actively pursued and clarified at present, in a manner which was not previously regarded as possible (19). One approach to handling the difficulties associated with the abstract concepts in animal welfare, while protecting scientific rigour, has been the proposal for a conceptual model (1). Such a model seeks to clarify the relationships between abstract concepts (e.g. consciousness), and to place the idea of suffering in an understandable context.

The simple elements of this conceptual model build on material from physiology, comparative psychology and pathology, to deal with a number of preconditions for suffering. These preconditions are inputs from the internal and external environment of animals and the processing, modulation and integration of these inputs by the nervous system to produce a range of responses. The key psychological considerations occur in a hierarchy or sequence. Consciousness is seen as a prerequisite for the capacity for subjective feeling or affect. Suffering occurs if this feeling or affect is unpleasant.

The conceptual model could have applications in clarifying and then structuring a systematic approach to the diagnosis, control and treatment of welfare problems in animals in all circumstances. This includes the international transport of animals, where there is a need to have an accepted frame of reference for welfare considerations. With regard to practical veterinary medicine, the methods developed for the diagnosis of disease states can be adjusted for the diagnosis of states which raise welfare concern. 


\section{Stress}

Stress is an important systemic state for animal welfare, as stress may be associated with suffering. Stress appears when the mechanisms in animals for coping with their environment become over-extended and begin to break down. The environmental factors which produce stress when they act excessively are termed stressors, and these include the following: inadequate nutrition, deprivation of water, heat, cold and overcrowding. Stress reduces the fitness of an animal and this can be expressed through disease and death, or failure to grow and breed (17).

The notion of stress is linked to the ideas of homeostasis, comfort zones, physiological reserve and the fight/flight or alarm reaction. Stressors can act differentially on different organ systems and sub-systems, and distinctly different responses are caused by different stressors, e.g. heat and cold. However, some general responses occur to all stressors, as described in the general adaptation syndrome, which defines three stages: alarm, maintenance of adjustment and then exhaustion (42). According to the model for humans, distress is the psychological manifestation of the stress complex and includes phenomena such as "tension, anxiety, worry, negative affect and emotions" (43).

The responses in the general adaptation syndrome are undertaken by the nervous system and by hormones produced by glands such as the pituitary, adrenal and thyroid. This fact has, in turn, focused attention on the physiology of the hypothalamic-pituitaryadrenal axis and the activity of adrenal corticoid hormones (12). The stress response is two-pronged, and the sympathetic nervous system works in conjunction with hormones from the adrenal medulla for certain short-term responses.

The following warnings with regard to the concept of stress have implications for other aspects of the diagnosis of welfare:

- stress is not identical with emotional arousal, nervous tension or harassment

- stress does not always accompany damage to an animal

- while blood concentrations of corticosteroids or other hormones may increase during stress responses, raised concentrations of these hormones alone do not provide a reliable measure of stress.

Stress is best monitored by changes in both behaviour and physiology.

\section{Stress and disease resistance}

The accompaniment of the stress response and the general adaptation syndrome by changes in the immune system and reduced resistance to infection is important and well-documented $(24,41)$. Accordingly, stress is linked with disease in two ways. Stress itself could be considered as a disease of adaptation (42) and can also predispose to other diseases.

\section{Disease}

Two important practical connections exist between disease and welfare:

- The presence of disease can indicate a breakdown in adequate husbandry and can signal underlying welfare problems. The incidence of disease is thus an elementary indicator of welfare in circumstances such as international transport. Disease incidence has been used as a basis for epidemiological analysis of the welfare issues in live sheep trade from Australia (40). 
- Disease itself can be accompanied by unpleasant feelings or suffering of various sorts. These are named in human experience as pain, headache, nausea, malaise, fever and depression. Disease is thus a reason for direct welfare concern and requires treatment in order to maintain welfare.

\section{Immunity as an indicator of welfare}

The onset of disease depends on other factors in addition to the presence of a primary causative agent. Resistance to infection is compromised by poor nutrition, exposure to extremes of climate and damaging social interactions. With regard to mechanisms, non-specific immunity, adaptive immunity or both can be compromised by environmental factors. Some, but not all, of the effects of these secondary causative factors of disease are mediated by the general adaptation syndrome and by the action of the hypothalamic-pituitary-adrenal axis. Adrenal corticoids, such as cortisone, which are released in stressful situations are known to interfere with immunity and to perturb populations of inflammatory cells (37). However, this is not the complete picture, as other humoral systems can be involved.

Ultimate expression of immune responses to infection is determined by regulatory mechanisms within the immune system and by co-operation between the immune system, the endocrine organs and the nervous system $(21,23)$. In other words, resistance arises due to both the way in which the immune system works and the way in which this system is allowed to work in relation to other bodily functions and demands. Immune function and components of the immune system can be measured. Accordingly, these may be useful indicators of the welfare of animals during transport. The activities of lymphocytes have been examined from this viewpoint (31).

\section{Specific disease problems related to transport}

The specific diseases, as opposed to general systemic states, which have long been associated with transport are either microbial or metabolic. These diseases include pasteurellosis ("shipping fever") in cattle, salmonellosis in all species and transit tetany, a complex metabolic disorder of ruminants. The disease picture for sheep during sea transport will be described later.

\section{WELFARE NEEDS AND WELFARE FACTORS ASSOCIATED WITH TRANSPORT}

\section{Welfare needs}

The idea of "needs" is important in animal welfare; this term refers to "a deficiency in an animal which can be remedied by obtaining a particular resource or responding to a particular environmental or bodily stimulus" (17). These needs vary according to the species, the physiological and behavioural status of individual animals, and circumstances. Pregnant and growing animals have specific needs related to these conditions. Equally, ill and injured animals have specific needs and, in most instances, these cannot be met during transport.

The concepts of "freedoms", "obligations" and "rights" are also applied to animal welfare. These refer to the moral responsibility of addressing the biological needs of animals under human care. A set of five freedoms has been listed, as follows (17):

- freedom from hunger and malnutrition

- freedom from thermal or physical distress 
- freedom from disease or injury

- freedom to express most normal behaviour

- freedom from fear (17).

International transport presents certain needs for animals which must be met by transporters. The set of needs for the safe carriage of sheep by sea has been described as $(13)$ :

a) sufficient palatable, nutritionally-balanced feed, adequate for physiological requirements

b) sufficient drinkable water

c) air which is free of noxious gases

d) an environment which provides the opportunity for behavioural expression and which does not cause undue physical restriction

e) natural or artificial protection from adverse weather conditions

f) protection from parasites, disease, predators and injury

g) access to suitable treatment (including prompt humane slaughter) when required.

\section{Factors influencing the welfare of animals during transport}

Various authors have listed the stressors acting on animals during transport. Hails (20) reviewed transport stress in animals, with particular emphasis on pigs, the "porcine stress syndrome", and road and rail transportation. The following stressors were listed:

- separation from a familiar environment and family groups

- loading and unloading

- overcrowding in confined spaces

- unfamiliar and loud noises

- vibration

- jolting

- extremes of temperature and humidity

- acceleration and deceleration during movement

- long periods of waiting during which there may be no ventilation, alternating with rapid air movement when the vehicle is in motion

- gases from faeces, urine and fumes

- changes in the biota of bacteria, etc. to which animals are exposed

- deprivation of feed and water.

Pearson and Kilgour (38) set out a similar list of factors to be considered in the transport of animals and aligned these with a set of physiological and behavioural variables which could be used to assess the degree of disturbance during the process. The factors were listed as follows:

- climatic conditions outside the range normally experienced by the animals

- handling and the degree of interaction with humans prior to the experience of transport 
- feed and water intake, and the possibility of a diminished appetite exacerbating various metabolic disorders

- exercise or the lack of it during transport

- social interactions and the breaking of bonds before transport (e.g. by weaning), and the forced interaction between unfamiliar animals during transport

- transport types and the various related mechanical factors such as jolting, swaying and vibration

- environmental changes such as new types of feed, and strange smells and sights

- the duration of transport.

The physiological variable considered was plasma concentration of corticosteroids. Behavioural variables were restlessness, body orientation to direction of movement, agonistic interaction (fighting and aggression), and behaviour at off-loading.

Stephens (44) classified the adverse stimuli associated with transportation as physical or emotional disturbances, and related these to the broad responses elicited by stressors. Fear received special mention as an emotion which can trigger the physiological responses of alarm and stress.

\section{Adaptation by animals to the process of transportation}

A major theme of the present article is that animals can be transported between countries by road, rail, air or sea in a manner which is compatible with good welfare. The key elements are the capacity of animals to adapt to the conditions of transport and an understanding of the principles which determine good conditions for transport.

With regard to the processes for adaptation, the contradictory idea that adaptive changes to stressors may themselves be detrimental, rather than beneficial to welfare is important (17). The functions of adaptation, learning and acclimation are also important. These adaptive capacities can and should be stimulated before transport occurs, and the related adaptive changes may be monitored.

The general importance of the processes of adaptation for transportation welfare has been highlighted in a systematic programme of epidemiological and experimental research related to the transport of sheep by sea $(32,33,34,35,36,40)$. Thermal acclimation and acclimatisation, for instance, are slower processes than the general stress response and will involve different physiological pathways. In this connection, the physiological distinction between acclimation and acclimatisation has practical significance. Acclimation is the persisting change in a specific function due to prolonged exposure to an environmental condition, such as high or low temperature, whereas acclimatisation is the persisting spectrum of changes to an environmental condition.

Time must be allowed for the necessary digestive adaptations to changes in diet, particularly in ruminants. Populations of ruminal microflora must adjust to changes in feed rations. Furthermore, diet selection in animals such as sheep involves behavioural intricacies which are now being explored. This may all occur at a time when there is a greater nutritional need for protein and energy.

\section{Challenges for adaptive responses by animals}

Several areas cause problems for adaptation. The absence of the environmental sensory stimuli to which an animal had previously been attuned and the loss of a 
previous routine may themselves constitute important stressors. Disorientation resulting from the loss of routine may complicate the response to new stressors, particularly for species such as sheep, which easily express fear at any new situation. In some cases, animals may fail to mount a stress response, or may exhibit only a partial response. As a result, life processes may collapse because no adaptation has been made to a stressful situation. This situation may occur more frequently in poikilotherms, e.g. reptiles. In addition, environmental factors may interact in unexpected ways, and the relative importance of different stressors to different species may be unpredictable. Finally, pregnant or growing animals and ill or injured animals have a restricted capacity to adapt to demands placed on them by transport.

\section{PRACTICALITIES OF INTERNATIONAL TRANSPORT}

Four fundamental considerations with regard to animal welfare during transport were identified in a report made by the Australian Parliament in 1991 (9). These considerations can be applied to international transport:

a) Steps such as collection, assembly, loading and unloading are common to all forms of animal transport and present particular animal welfare hazards. Quality control procedures can be applied at all these stages.

b) Economic and animal welfare factors do not necessarily work against one another. There must be a strong financial incentive to prevent disease stress and disease, and to protect welfare during transport.

c) Rules and regulations are important in the protection of animals, but the quality of care is ultimately determined by the skills and attitudes of people. If the care of animals can be explained in biological terms, it can be taught and learned through either informal or formal processes.

d) Animal welfare will be improved by any measures which reduce either the length or the number of journeys. This does not contradict the idea that animals can be transported over long distances and for long times under suitable conditions, but rather recognises that the degree of risk is related to the amount of exposure to potential hazards. Thus direct sale and movement of slaughter animals from farms into nearby abattoirs, without intermediate travel to livestock markets, has clear-cut benefits for welfare.

\section{Non-domesticated animals}

The United Nations Environment Program (UNEP), through the Convention on International Trade in Endangered Species of Wild Fauna and Flora (CITES), has published guidelines for the transport and preparation for shipment of wild animals (4). These guidelines deal with husbandry and thus automatically involve welfare.

\section{Road transport}

Road transport can be classified into three categories: short, medium and long haul. The difference between these categories is significant for welfare, in view of the time involved and because different types of vehicles may be used. Specific considerations for road transport include the following:

- vehicle design standards related to the comfort of livestock

- standards for loading and unloading facilities 
- the use of goads (electric or otherwise)

- loading densities

- rest periods

- times for feeding and watering

- measures for responding to road accidents where livestock are injured.

Interdisciplinary work is being performed by biologists and engineers to design both loading and unloading facilities (26) and vehicles, particularly for circumstances where roads are unpaved (25).

Australian guidelines for road transport of animals (9) require that rest periods of between 12 and 24 hours be provided after each 24-hour travel period for horses, pigs and young ruminants under 3 months of age. The period of travel for these species may be extended to 36 hours if the animals are rested for 24 hours before the next stage of the journey. For mature sheep, cattle, goats and buffalo, the period of travel is 36 hours before a rest period of 12-24 hours, and this can be extended to 48 hours if a 24 -hour period is given for rest. In Europe at present, the maximum duration of travel is 24 hours before periods for rest, watering and feeding. These figures are arbitrary and must be regarded as merely indicative and secondary in importance to the systematic monitoring of the condition of animals being transported.

\section{Rail transport}

The requirements for rail transport are essentially similar to those for road transport, centering on standards for vehicles, rest periods, and times for feeding and watering. Rail transport has the disadvantage of necessitating repeated handling of livestock; namely, the loading and unloading from road transport at the start and finish of the journey. In many parts of the world, conditions for the rail transport of animals, including the stockmanship involved, are considered poorer than those for road transport. Rail transport of farm animals is less favoured and has been completely abandoned in some areas of Australia.

\section{Sea transport}

The conditions for transport of animals by sea have improved with general improvements in ship design for seaworthiness and comfort, and advances in aids for navigation which increase the opportunity for avoiding heavy weather (15). The region comprising Oceania, Australia and New Zealand has always had a stake in sea transport of animals, and the present domestic species were introduced into the region by this route. The current export of live sheep from Australia has been described as "the largest, planned mass movement of animals by sea in the history of the world" (6).

\section{Sheep}

The export of live sheep from Australia has provided a valuable body of knowledge on the animal welfare aspects of sea transport. Judging by mortality rates, this knowledge has significantly alleviated disease and stress and improved the welfare of the sheep involved; some shipments give rise to negligible mortality. These improvements have been effected by the design of ships specially equipped to transport sheep, and with forced air ventilation to deliver appropriate air changes throughout animal holding areas. In addition, controls have been placed on nutrition, and quality-assured pellets are administered during transport in purpose-designed troughing. 
Mortality rates still cause concern and have prompted concerted attempts to understand the causes and deliver appropriate solutions. The picture drawn by current investigations suggests that the problems are open to solution, and that the solutions may have wider applications in other aspects of animal husbandry. Many of the findings have been contrary to expectations. Fat sheep run twice the risk of dying from the "failure-to-eat" syndrome as lean sheep. In addition, some lines of sheep are more prone to mortality than others.

The body of scientific knowledge which has been used to address welfare problems in sea transport of sheep from Australia has resulted from a combination of experience, methodical observation and epidemiological analysis of data, and deliberate experimentation. This knowledge appears to have been assembled during several phases, as the industry expanded and design of the vessels changed. The research falls into the following three categories: disease and mortality; feeding and husbandry systems; and nutrition.

The first phase of investigations into the sea transport of sheep terminated with the introduction of purpose-built sea vessels and a drop in the mortality rate. Obvious nutritional problems were addressed. The hay ration which had been routinely fed until that time was inadequate. In 1986, national standards were adopted for preembarkation feedlots and, in 1988, similar standards were adopted for pelleted feed (7); considerations include nutritional value, durability, and pellets as a fire hazard. It is now clear that sheep require $20-30 \%$ more feed during the voyage to maintain bodyweight than was indicated by previous estimates (29).

The second phase was characterised by official reports into the problems of sea transport (5), and reviews of relevant technical background information $(18,45)$; the third phase was a period of consolidation and consideration of approaches.

The thrust of investigations now centres on diagnosis, with a thorough and continuing epidemiological analysis of mortality at all stages of the process of live sheep export $(32,33,34,35,36,40)$.

At present, approximately $2 \%$ of sheep die during the voyage and the unloading stage. A major study (40) reported the following disorders as causing mortality in sheep during the sea transport stage of live export (proportional incidence in brackets):

- inanition/failure to eat (43\%)

- salmonellosis $(20 \%)$

- $\operatorname{trauma}(11 \%)$

- enterotoxaemia (1\%)

- miscellaneous (including degenerative myopathy, lupinosis, foot abscess, urinary calculi and pneumonia) (6\%).

There were virtually no deaths from acute carbohydrate engorgement and acidosis. Death rates vary in acordance with the background of sheep, and half of all deaths have been shown to occur in $13 \%$ of the identified farm groups (33).

Failure to eat, obesity, age, season of the year, and temperature and humidity are all important factors in mortality. Failure to eat is a complicated phenomenon which raises basic questions about the physiological and behavioural aspects of diet selection and appetite in sheep (27), and the ways in which disruption can occur. Processes of learning are also important (28), as are the neural pathways of the central nervous system, 
particularly the nausea centre which acts as a master switch and can be activated by stimuli other than feed (39). Obese sheep are more prone to the failure to eat/inanition syndrome than lean sheep, and this relates to the mobilisation of stored fat and the impact of this process on appetite. Similarly, older wethers were more prone to the inanition syndrome than growing sheep. Finally, there was evidence of an annual rhythm to mortalities, which focuses attention on the possibility of a hitherto unrecognised seasonal control of metabolism in sheep.

Epidemiological studies have provided reliable signposts for the next phase of action for the health and welfare of sheep during sea transport. This will be the formulation and implementation of control measures tailored to an understanding of the biological processes which are disrupted during transportation. An initial observation has been made that a synthetic corticosteroid can forestall the failure to eat/inanition syndrome (2). This suggests a possible control measure and sheds light on mechanisms which might be susceptible to other forms of intervention.

\section{Cattle}

Cattle tend to experience fewer welfare problems than sheep during sea transport, as indicated by mortality rates. However, species comparisons may be spurious. Many problems can be forestalled by adequate preconditioning of cattle before embarkation, particularly if cattle have had little contact with people and have not previously been fed by hand. Hyperthermia and limb abrasions have been identified as the usual causes of mortality and rejection in slaughter cattle transported by sea (8).

\section{Other animals}

In the past, when horses were a major form of military transport, large numbers of these animals were moved by sea and a large body of common-sense knowledge was acquired with regard to the appropriate husbandry. Horses had to be fit and ready for service when they arrived at their destination. In this context, husbandry equates (to a large extent) with welfare. The section on sea transport of horses included in the 1933 British army manual on animal management remains relevant and illuminating (3).

In recent years, there has been regular traffic of water buffalo (Bubalus bubalis) from northern Australia to countries in South-East Asia. The welfare considerations for the transport of this species are the same as for other large members of the Subfamily Bovinae. Australian water buffalo are feral, but these animals rapidly adapt to unusual conditions, such as capture and transport, and respond favourably to handling and human contact. The large horns of water buffalo pose a problem during transport, and it is beneficial to remove the tips. Water buffalo do not have a thick hair coat to protect them from radiant heat and are prone to dehydration; these factors must be considered during handling and transport.

Experience shows that specific welfare problems are presented by goats during sea transport, and feral goats from the rangelands of Australia appear to require special treatment. Such animals must adapt to captivity and contact with humans, in addition to coping with the stressors encountered during actual transportation.

The welfare provisions for the sea transport of sheep can be applied only in principle to goats, in view of the many differences between these species in terms of physiology and behaviour. These include the following:

- Goats may require a longer period of preconditioning in pre-embarkation feedlots. 
- Feeding behaviour and the range of digestive disturbances are different.

- Arousal by environmental stimuli may be more intense and persistent in goats than in sheep, and may be accompanied by a more pronounced physiological stress response.

\section{Air transport}

Many former concerns with regard to air transport of animals have been satisfied by advances in the design of aircraft and the application of regulations contained in the comprehensive manual of the International Air Transport Association (11). These regulations have become the accepted guidelines for CITES and the Office International des Epizooties (OIE), and have been employed by the Council of Europe in the development of codes of conduct for the transport of animals.

\section{CONCLUSIONS}

The continuing increase in international transport of animals raises shared concerns about welfare, stress and disease, and argues for the development of regulatory procedures and principles to prevent problems and to deal with these when they occur. Discussions prompted by these concerns require an intelligible frame of reference, which could be provided in the form of a conceptual model aimed at dealing with the complex of abstract ideas involved in welfare, without compromising scientific rigour. The details of this model could be adjusted according to particular knowledge of a given species.

All modes of international transport are potentially hazardous for animals and can lead to disease, stress and compromised welfare. These three entities are inextricably related. Welfare is described as "the state of an individual [animal] as regards its attempts to cope with its environment" (14). Disease and stress are important to welfare, as these states occur in individual animals. In addition, disease and stress are linked functionally: stress can be a disease state itself and can also reduce resistance to infectious disease.

The welfare of animals relates to life processes which can be described and appraised by the language and principles of biology, and which are open to scientific analysis. However, animal welfare is a matter for both science and morality, and neither domain alone is sufficient for understanding or action on behalf of animals. Evidence and descriptions of the state of animals provide the material for ethical evaluation.

Practical measures to improve the welfare of animals can be based on the body of scientific knowledge which has resulted from both experience with transport and experimental investigation. The practicalities of animal welfare relate to the preparation, assessment and selection of animals before transport, and to the provision of suitable environments, feed, water, comfort and rest during transport, and arrangements for recovery and restoration after transport. 


\section{LE TRANSPORT ET LE BIEN-ÊTRE DES ANIMAUX. - D.B. Adams.}

Résumé : Tous les modes de transport présentent des risques pour les animaux, qu'il s'agisse de déplacements nationaux ou internationaux, par voie routière ou ferroviaire, aérienne ou maritime. Cependant, l'expérience montre que les animaux peuvent être transportés dans de bonnes conditions et sans souffrance.

Assurer des conditions satisfaisantes et fournir un cadre applicable à la réglementation du transport international des animaux qui soit acceptable par tous, passe par une bonne compréhension des besoins en termes de bien-être des animaux ainsi que des dimensions biologiques de la maladie, du stress et de la souffrance. L'auteur examine ce cadre d'un point de vue biologique.

La faculté d'adaptation aux contraintes des différents modes de transport varie selon les espèces et la condition physique des animaux transportés. C'est pourquoi plusieurs règles élémentaires doivent être respectées : préparer et sélectionner les animaux avant le transport, leur assurer des conditions de vie, d'alimentation, d'abreuvement et de repos convenables en cours de déplacement, et veiller aux conditions de leur récupération à l'arrivée. Quant aux animaux malades ou blessés, il ne doivent pas être transportés.

MOTS-CLÉS : Bien-être des animaux - Maladie - Stress - Transport.

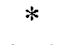

* *

\section{TRANSPORTE Y BIENESTAR DE LOS ANIMALES. - D.B. Adams.}

Resumen: Todos los modos de transporte representan riesgos para los animales, se trate de desplazamientos nacionales o internacionales, por vía terrestre, en rutas o en ferrocarril, o por vía aérea o marítima. Pero, a la vez, la experiencia ha mostrado en todos los casos que es posible transportar animales en buenas condiciones y sin causarles sufrimiento.

Para garantizar condiciones satisfactorias en este sentido ofreciendo también un marco que se pueda aplicar a la reglamentación del transporte internacional de animales aceptable por todos, se requiere una buena comprensión previa tanto de las necesidades en materia de bienestar de los animales como de las dimensiones biológicas de la enfermedad, del estrés y del sufrimiento. El autor examina este marco desde un punto de vista biológico.

La facultad de adaptación a las dificultades de los distintos modos de transporte varía con las especies y las condiciones físicas de los animales transportados. Es necesario respetar varias reglas elementales: preparar y seleccionar los animales antes del transporte, garantizarles condiciones adecuadas en cuanto a medio ambiente, alimentación, bebida y descanso durante el viaje y asegurar su recuperación al llegar a destino. Por otra parte, debe excluirse el transporte de animales enfermos o heridos.

PALABRAS CLAVE: Bienestar de los animales - Enfermedad - Estrés Transporte. 


\section{REFERENCES}

1. ADAMs D.B. (1992). - The welfare of sheep. In The behaviour of sheep: biological principles and implications for production (J.J. Lynch, G.N. Hinch \& D.B. Adams, eds). Centre for Agriculture and Biosciences International, Wallingford, Oxon, United Kingdom; and Commonwealth Scientific and Industrial Research Organisation (Australia), East Melbourne, Australia, 178-210.

2. ADAMS N.R. \& SANDERS M.R. (1992). - Improved feed intake and body weight change in sheep treated with dexamethasone at entry into pens or feedlots. Aust. vet. J., 69, 209-213.

3. ANON. (1933). - Animal management; prepared in the Veterinary Department of the War Office. His Majesty's Stationery Office, London, United Kingdom, 379 pp.

4. ANON. (1980). - Guidelines for transport and preparation for shipment of live wild animals and plants: a manual for shippers, handlers and importers of wild live animals and plants, with particular reference to the species protected by the Convention on International Trade in Endangered Species of Wild Fauna and Flora. United Nations Environment Program, New York, United States of America, 109 pp.

5. ANON. (1981). - Sea transport of sheep. Australian Bureau of Animal Health, Australian Government Publishing Service, Canberra, Australia, 40 pp.

6. Anon. (1985). - Export of live sheep from Australia. Report by the Senate Select Committee on Animal Welfare. Australian Government Publishing Service, Canberra, Australia, $228 \mathrm{pp}$.

7. Anon. (1988). - National pellet standards for the live sheep export industry. Department of Primary Industries and Energy, Canberra, Australia, 12 pp.

8. Anon. (1988). - Standing Committee on Agriculture Workshop on Livestock Export Research. Australian Government Publishing Service, Canberra, Australia, 344 pp.

9. AnON. (1991). - Transport of livestock within Australia. Report by the Senate Select Committee on Animal Welfare. Australian Government Publishing Service, Canberra, Australia, $72 \mathrm{pp}$.

10. AnON. (1992). - 1990 International Trade Statistics Yearbook, Vol. 2. United Nations, New York, United States of America, 1,265 pp.

11. Anon. (1992). - IATA Live Animals Regulations, 19th Ed. International Air Transport Association, Montreal, Canada, 234 pp.

12. Bateman A., Singh A., Kral T. \& Solomon S. (1989). - The immune-hypothalamicpituitary-adrenal axis. Endocr. Rev., 10, 92-113.

13. Brennan R.G., Beckett R.J., Nurthen E.J. \& Cannon R.M (1988). - The shipboard veterinary clinical service. How many sheep make a mob? In Bureau of Rural Resources Proceedings No. 3, Standing Committee on Agriculture Workshop on Livestock Export Research. Australian Government Publishing Service, Canberra, Australia, 72-85.

14. BRoOM D.M. (1986). - Indicators of poor welfare. Br. vet. J., 142, 524-526.

15. DEERE D. (1983). - Animal transport by sea. Marine Publications International, London, United Kingdom, 82 pp.

16. EWBANK R. (1988). - Animal welfare. In Management and welfare of farm animals. The Universities Federation for Animal Welfare Handbook, 3rd Ed. Ballière Tindall, London, United Kingdom, 1-12.

17. Fraser A.F. \& BRoOM D.M. (1990). - Farm animal behaviour and welfare. Ballière Tindall, London, United Kingdom, 437 pp. 
18. GRandin T. (1983). - A survey of handling practices and facilities used in the export of Australian livestock. Australian Government Publishing Service, Canberra, Australia, $30 \mathrm{pp}$.

19. GrifFin D.R. (1992) - - Animal minds. The University of Chicago Press, Chicago, United States of America, $310 \mathrm{pp}$.

20. Hails M.R. (1978). - Transport stress in animals: a review. Anim. Regul. Stud., 1, 289-343.

21. HaRT B.L. (1988). - Biological basis of the behavior of sick animals. Neurosci. Biobehav. Rev., 12, 127-137.

22. HumE C.W. (1986). - How to befriend laboratory animals. In Man and beast. Universities Federation for Animal Welfare, South Mimms, Herts, United Kingdom, 6-9.

23. JANKOVIC B.D. (1989). - Neuroimmunomodulation: facts and dilemmas. Immun. Lett., 21, 101-118.

24. Kelley K.W. (1980). - Stress and immune function. A bibliographic review. Ann. Rech. vét., 11, 445-478.

25. Lapworth J.W. (1986). - Advances in road transportation. Proc. Aust. Soc. Anim. Prod., 16, 114-115.

26. LAPWORTH J.W. (1990). - Standards for loading and unloading facilities for cattle. Appl. Anim. Behaviour Sci., 28, 203-211.

27. LYNCH J.J. (1992). - Grazing behaviour in sheep. In The behaviour of sheep: biological principles and implications for production (J.J. Lynch, G.N. Hinch \& D.B. Adams, eds). Centre for Agriculture and Biosciences International, Wallingford, Oxon, United Kingdom; and Commonwealth Scientific and Industrial Research Organisation (Australia), East Melbourne, Australia, 9-47.

28. LYNCH J.J. \& BELL A.K. (1987). - The transmission from generation to generation in sheep of the learned behaviour for eating grain supplements. Aust. vet. J., 64, 291-292.

29. McDonald C.L., Warken B.E., Richards R.B., Gittins S.P., Bunny C.J. \& Fry J. (1990). - Feeding level to maintain liveweight of merino wethers under simulated shipping. Proc. Aust. Soc. Anim. Prod., 18, 522.

30. Moss R. (ed.) (1982). - Transport of animals intended for breeding, production and slaughter. Martinus Nijhoff Publishers, The Hague, Boston and London, $236 \mathrm{pp}$.

31. Murata H. (1989). - Suppression of lymphocyte blastogenesis by sera from calves transported by road. Br. vet. J., 145, 257-262.

32. NoRRIS R.T. \& Richards R.B. (1989). - Deaths in sheep exported by sea from Western Australia - analysis of ship Master's reports. Aust. vet. J., 66, 97-102.

33. NorRis R.T., Richards R.B. \& DunLop R.H. (1989). - An epidemiological study of sheep deaths before and during export by sea from Western Australia. Aust. vet. J., 66, 276-279.

34. NoRRis R.T., RichaRdS R.B. \& DuNLOP R.H. (1989). - Pre-embarkation risk factors for sheep deaths during export by sea from Western Australia. Aust. vet. J., 66, 309-314.

35. Norris R.T., McDonald C.L., Richards R.B., Hyder M.W., GitTins S.P. \& Norman G.J. (1990). - Management of inappetant sheep during export by sea. Aust. vet. J., 67, 244-247.

36. Norris R.T., Richards R.B. \& Norman G.J. (1992). - The duration of lot-feeding of sheep before transport. Aust. vet. J., 69, 8-10. 
37. OPPENHEIM J.J. \& SHEVACH E.M. (eds) (1990). - Immunophysiology. Oxford University Press, New York, United States of America, 424 pp.

38. PEARson A.J. \& Kilgour R. (1980). - The transport of stock - an assessment of its effects. In Reviews in rural science, Vol. IV: Behaviour (M. Wodzicka-Tomaszewska, T.N. Edey \& J.J. Lynch, eds). University of New England, Armidale, New South Wales, Australia, 161-165.

39. Provenza F.D., Pfister J.A. \& Cheney C.D. (1992). - Mechanisms of learning in diet selection with reference to phytotoxicosis in herbivores. J. Range Management, 45, 36-45.

40. Richards R.B., Norris R.T., Dunlop R.H. \& MCQuade N.C. (1989). - Causes of death in sheep exported live by sea. Aust. vet. J., 66, 33-38.

41. RILEY V. (1981). - Psychoneuroendocrine influences on immunocompetence and neoplasia. Science, 212, 1100-1109.

42. SELYE H. (1976). - Stress in health and disease. Butterworths, London, United Kingdom, $1,256 \mathrm{pp}$.

43. Steinberg A. \& Ritzmann R.F. (1990). - A living systems approach to understanding the concept of stress. Behav. Sci., 35, 138-146.

44. STEPHENS D.B. (1982). - Transport of animals intended for breeding, production and slaughter. In Transport of animals intended for breeding, production and slaughter (R. Moss, ed.). Martinus Nijhoff Publishers, The Hague, Boston and London, 187-205.

45. SYME L.A. (1985). - Intensive sheep management with particular reference to the live sheep trade. Australian Government Publishing Service, Canberra, Australia, 57 pp.

46. TANNENBAUM J. (1991). - Ethics and animal welfare: the inextricable connection. J. Am. vet. med. Assoc., 198, 1360-1376. 